\title{
Eight new species of genus Camellocossus Yakovlev, 2011 (Lepidoptera: Cossidae) from North and East Africa
}

\author{
Восемь новых видов рода Camellocossus Yakovlev, 2011 \\ (Lepidoptera: Cossidae) из Северной и Восточной Африки
}

\author{
R.V. Yakovlev ${ }^{1,2}$, Th.J. Witt ${ }^{3}$ \\ P.В. Яковлев ${ }^{1,2}$, Т.Витт ${ }^{3}$
}

\footnotetext{
${ }^{1}$ Altai State University, Lenina pr. 61, RF-656049 Barnaul, Russia. E-mail: yakovlev_asu@mail.ru

${ }^{1}$ Алтайский государственный университет, пр. Ленина 61, г. Барнаул 656049, Россия.

2 Tomsk State University, Lenina pr. 36, 634050 Tomsk, Russia.

2 Томский государственный университет, пр. Ленина 36, Томск, 634050 Россия.

${ }^{3}$ Museum Witt, Tengstrasse 33, D-80796, Munich, Germany. E-mail: thomas@witt-thomas.com
}

KEY WORDS. Cossidae, Carpenter moths, Camellocossus, Africa, Arabia, new species, fauna.

КЛЮЧЕВЫЕ СЛОВА: Cossidae, древоточцы, Camellocossus, Африка, Аравия, новый вид, фауна.

ABSTRACT. The paper presents new data on the systematics and the distribution of species of the genus Camellocossus Yakovlev, 2011 (Lepidoptera: Cossidae). Eight new species are described. The descriptions of all the new species (the adults and male genitalia) are illustrated. A distribution map of the species of Camellocossus is given. It is established that the genus Camellocossus is common component of East Africa, and the deserts of North Africa and the Arabian Peninsula.

РЕЗЮМЕ. Представлены новые сведения по систематике и распространению видов рода Camellocossus Yakovlev, 2011 (Lepidoptera: Cossidae). Описано восемь новых видов. Описания всех новых видов проиллюстрированы (габиту, гениталии самцов). Приведена карта распространения рода Camellocossus. Установлено, что Camellocossus - общий компонент фауны Восточной Африки, пустынь Северной Африки и Аравийского полуострова.

\section{Introduction}

Cossidae are a family of ditrysian lepidoptera including about 1000 species [Yakovlev, 2015] distributed worldwide except for the Polynesian islands and high latitudes. Cossidae are most widespread in the Paleotropic Region [Yakovlev, 2011, 2015]. An analysis of the distribution of known Cossidae species from arid and sub-arid regions of the Palearctic and Afrotropics including the Sahara is given by Yakovlev and Dubatolov [2013] and Yakovlev [2015]. One of the typical eremic genera is Camellocossus Yakovlev, 2011. The genus Camellocossus was established for Cossus abyssinica (Hampson 1910) [Yakovlev, 2011]. A brief revision of the genus Camellocossus was published recently [Yakovlev et al., 2015]. Currently, the genus Camellocossus includes four species [Yakovlev et al., 2015]: C. abyssinica (Hampson, 1910) (Figs 1, 22) (Northern Ethiopia), C. henleyi [Warren, Rothschild, 1905] (Figs 2, 22) (Sudan, Egypt), C. osmanya Yakovlev, 2011 (Figs 3, 22) (Somalia), and C. sindbad Yakovlev et Saldaitis, 2015 (Figs 4, 22) (S. Oman).

Studying new material of Cossidae from Morocco, Algeria, Sudan, Ethiopia, and Kenya in the Museum Witt (Munich) and in the collection of M. Ströhle (Weiden), eight new species of the genus Camellocossus were discovered. Their descriptions and diagnoses are given below.

\section{Material and methods}

All specimens were collected using light traps. The preparation of genitalia is necessary for the identification of Cossidae. Dissections were performed with standard methods. Male genitalia were mounted in euparal on slides following Lafontaine [2004]. The genitalia slides were examined with the use of the Zeiss Stemi $2000 \mathrm{C}$ microscope, the images were taken with the Olympus XC 50 camera and processed in Corel PHOTO-PAINT 11 Windows ${ }^{\circledR}$ software. Photos of imago where taken using the camera Canon PowerShot SX50HS.

\section{Results}

Camellocossus aladdin Yakovlev et Witt, sp.n. Figs 5, 13, 21, 23.

MATERIAL. Holotype, O', Morocco, W. Goulmin, $483 \mathrm{~m}$, $\mathrm{N} 29^{\circ} 07.655^{\prime} / \mathrm{W} 10^{\circ} 01.476^{\prime}$, leg. H. Sulak (Museum Witt, Munich; GenPr Heterocera MWM 25.275). Paratypes: $3 \sigma^{7} \sigma^{7}$, same data as holotype (Museum Witt, Munich).

DESCRIPTION. Length of fore wing $14 \mathrm{~mm}$. Antennae short, in length equal to $1 / 3$ of forewing costal margin. Head, 
thorax and abdomen densely covered with brown scales. Forewing dark grey with thin undulated pattern; basal area grey with single black transverse strokes, two thin black transverse bands converging to rear margin of wing in discal area; brown portion in cubital region; in submarginal area thin black band curved in cubital region; fringe grey unicolorous. Hind wing pale ocher with poorly expressed grey sputter.

Male genitalia. Uncus elongated with rounded apex; tegumen of medium size; gnathos arms thin, of medium length; gnathos of medium size, densely covered with small spikes; valve wide with parallel margins, long poorly expressed crest with practically even edge at costal margin, thin transverse rib on inner surface of valve in preapical area, sacculus large, apex of valve rounded; transtilla process very long, thin, bent at an angle of $90^{\circ}$ in its middle third, narrowed sharply in its proximal third, apex tapered; juxta large, heavily sclerotized, with two leaf-like lateral processes widening to apex and diluted at an angle of $90^{\circ}$; inner surface of lateral process of juxta with two transverse sclerotized folds;



1
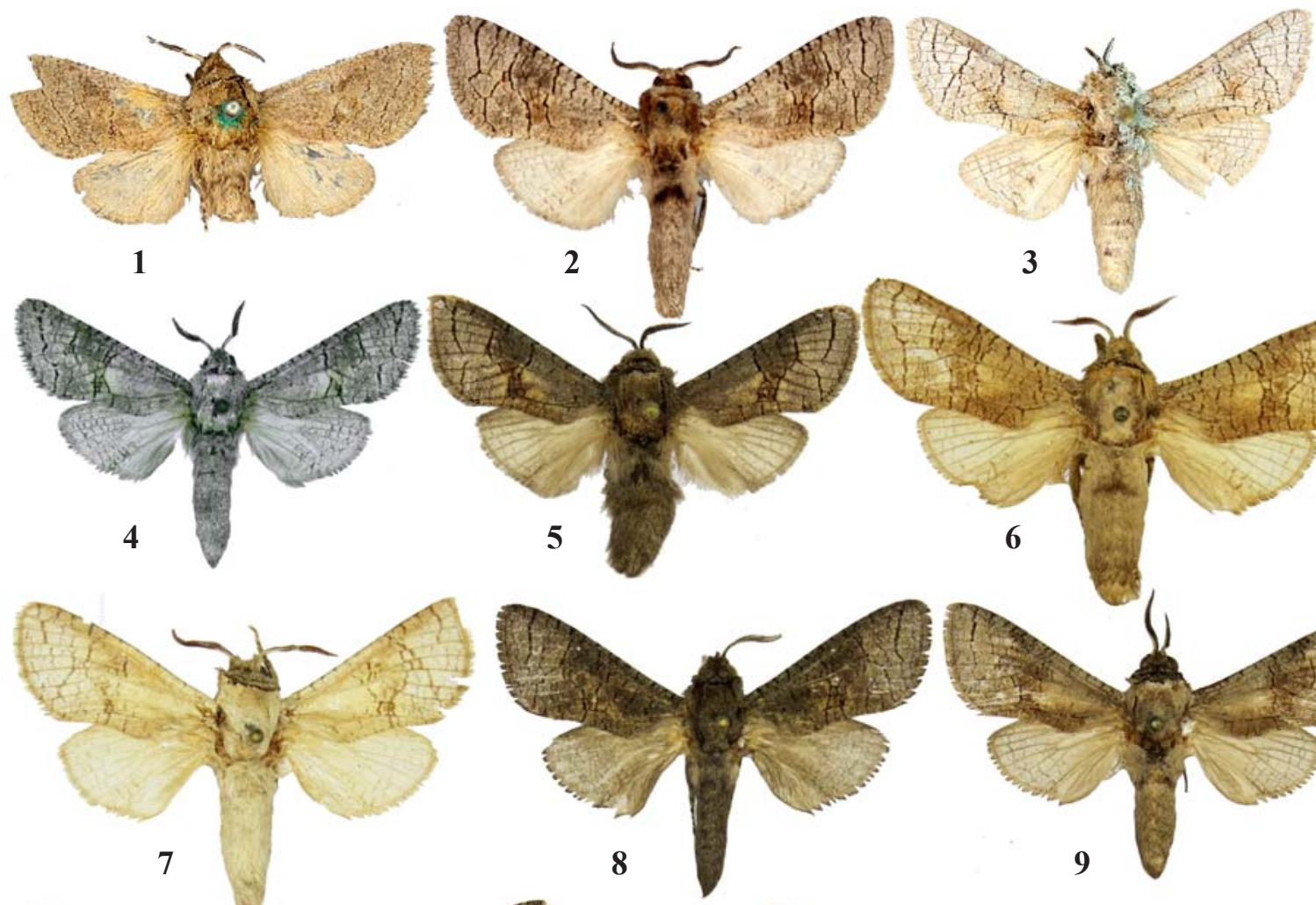

6
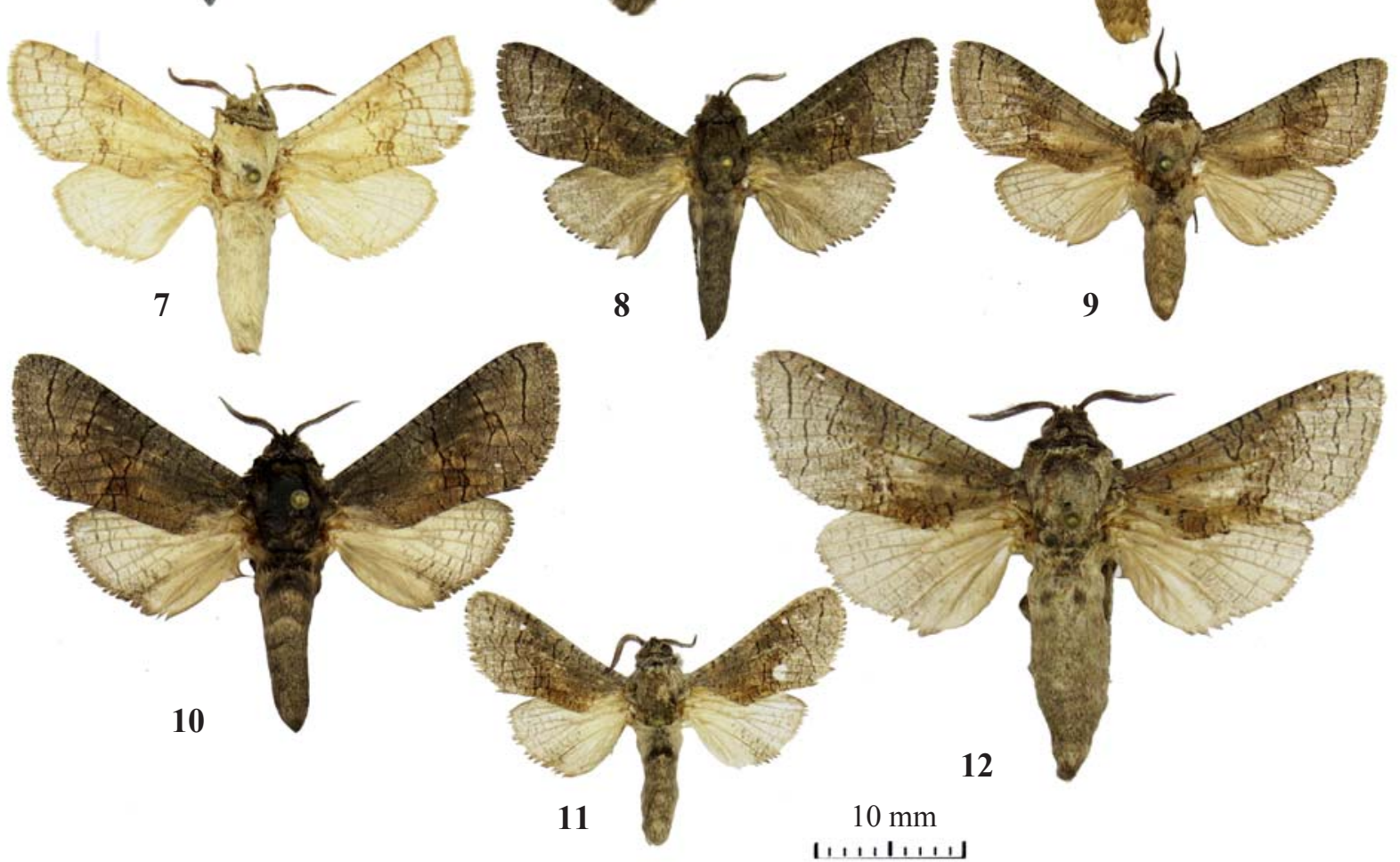

Figs 1-12. Adult males of Camellocossus species, holotypes: $1-$ C. abyssinica (Hampson, 1910); 2 - C. henleyi (Warren et Rothschild 1905); 3 - C. osmanya Yakovlev, 2011; 4 - C. sindbad Yakovlev et Saldaitis, 2015; 5 - C. aladdin Yakovlev et Witt, sp.n.; 6 - C. roc Yakovlev et Witt, sp.n.; $7-$ C. jinn Yakovlev et Witt, sp.n.; $8-$ C. ifrit Yakovlev et Witt, sp.n.; 9 - C. strohlei Yakovlev et Witt, sp.n.; $10-$ C. lalibela Yakovlev et Witt, sp.n.; $11-$ C. snizeki Yakovlev et Witt, sp.n.; $12-$ C. ngai Yakovlev et Witt, sp.n.

Рис. 1-12. Самцы видов Camellocossus, голотипы: 1 - C. abyssinica (Hampson, 1910); 2 - C. henleyi (Warren et Rothschild 1905); 3-C. osmanya Yakovlev, 2011; 4 - C. sindbad Yakovlev et Saldaitis, 2015; 5-C. aladdin Yakovlev et Witt, sp.n.; 6-C. roc Yakovlev et Witt, sp.n.; $7-$ C. jinn Yakovlev et Witt, sp.n.; $8-C$. ifrit Yakovlev et Witt, sp.n.; 9 - C. strohlei Yakovlev et Witt, sp.n.; $10-C$. lalibela Yakovlev et Witt, sp.n.; $11-$ C. snizeki Yakovlev et Witt, sp.n.; $12-$ C. ngai Yakovlev et Witt, sp.n. 
saccus of medium size, semicircular; phallus thick, straight, in length about $4 / 5$ of valve, vesica aperture in dorsal-apical position, in length about $2 / 3$ of phallus; vesica without cornuti.

DIAGNOSIS. C. aladdin sp.n. is distinctive by the following characteristic features: dark background of the fore wing upper side; practically even long crest on the costal margin of the valve; one thin transverse rib on the inner surface of the valve; the lateral process of the transtilla is sharply narrowed in its proximal third; the lateral process of the juxta is leaf-like, apically widened, with two ribs on the inner side.

ETYMOLOGY. The new species is named after Aladdin - a character of Arabian tales.
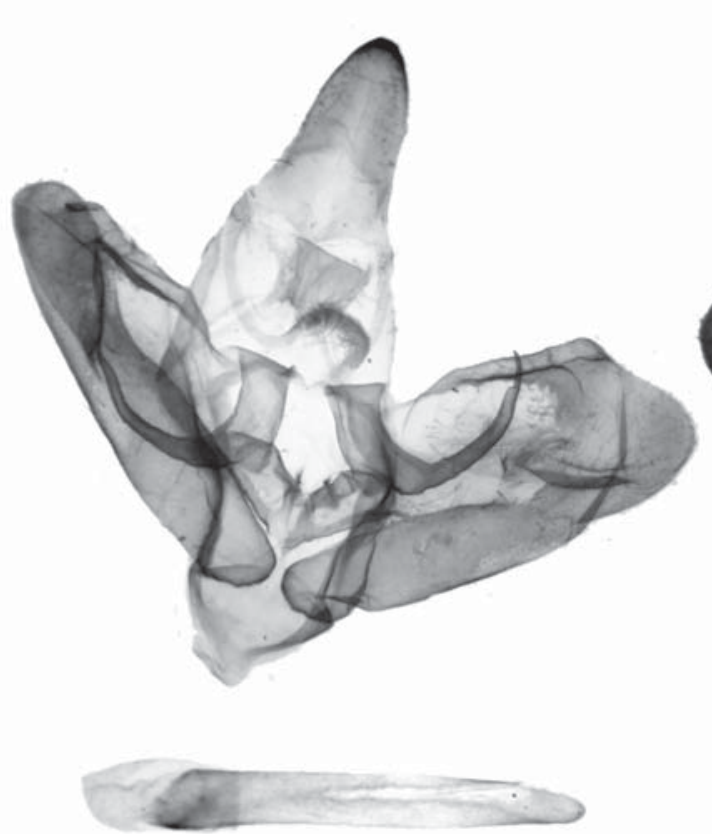

13



14
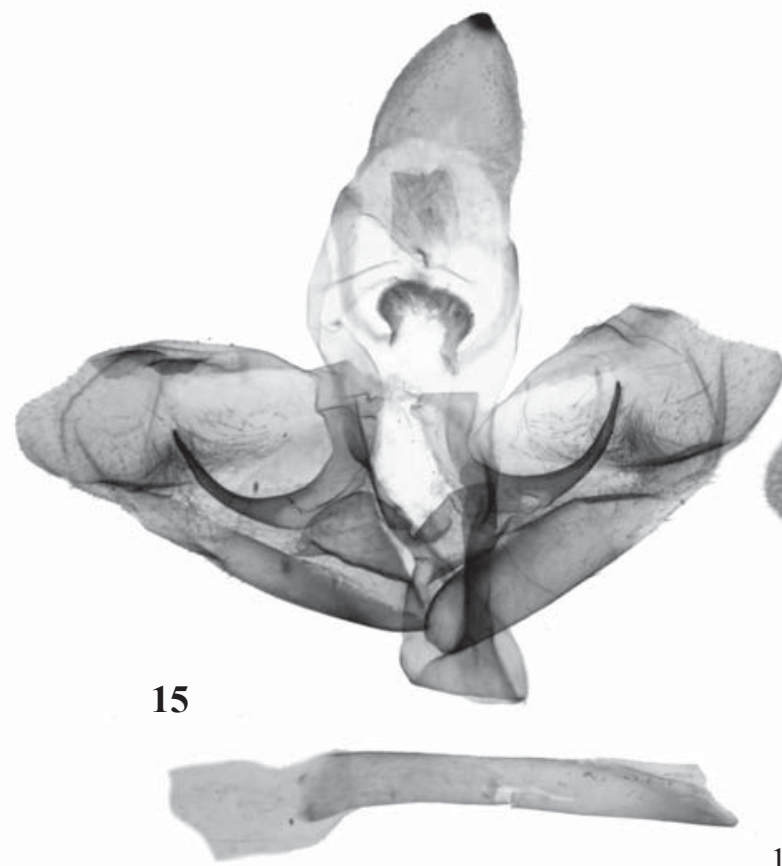


$1 \mathrm{~mm}$

$$
|1,1,1,1,|
$$

Figs 13-16. Male genitalia of Camellocossus species: $13-$ C. aladdin Yakovlev et Witt, sp.n.; $14-$ C. roc Yakovlev et Witt, sp.n.; $15-$ C. jinn Yakovlev et Witt, sp.n.; $16-$ C. ifrit Yakovlev et Witt, sp.n.

Рис. 13-16. Гениталии самцов видов Camellocossus: 13 - C. aladdin Yakovlev et Witt, sp.n.; $14-$ C. roc Yakovlev et Witt, sp.n.; $15-$ C. jinn Yakovlev et Witt, sp.n.; $16-$ C. ifrit Yakovlev et Witt, sp.n. 
Camellocossus roc Yakovlev et Witt, sp.n. Figs 6, 14, 23.

MATERIAL. Holotype, $\sigma^{7}$, Algeria, $50 \mathrm{~km}$ NÖ Tamanrasset [22 $\left.48^{\circ} \mathrm{N} / 05^{\circ} 30^{\prime} \mathrm{E}\right]$, 03.04.1989, leg. Kuhler jr. (collection of M. Ströhle, Weiden, Coss-MSW/2015/16). Paratype, 1 ○', Algeria, same data as holotype (collection of M. Ströhle, Weiden).

DESCRIPTION. Length of fore wing $17 \mathrm{~mm}$. Antennae short, in length equal to $1 / 3$ of fore wing costal margin. Head, thorax and abdomen densely covered with ocher scales. Fore wing ocher with thin undulated pattern rather uniformly spread throughout wing; blurred brown portion in discal area; thin black band in submarginal area; fringe pale brown, unicolorous. Hind wing pale ocher with poorly expressed grey sputter and single dark transverse strokes.

Male genitalia. Uncus thick, short with wide rounded apex; tegumen large; gnathos arms thick, of medium size; gnathos of medium size, densely covered with small spikes; valve wide with parallel margins, on costal margin long poorly expressed crest with small process on inner surface in distal third, sacculus of medium size, apex of valve rounded; transtilla process of medium size, uniformly curved, gradually narrowing from base to apex, apex tapered; juxta large, heavily sclerotized with leaf-like lateral processes with parallel edges diluted at an angle of $100^{\circ}$; saccus of medium size, semicircle; phallus thick, straight, in length about $4 / 5$ of valve, vesica aperture in dorsal-apical position, in length about $1 / 2$ of phallus; vesica without cornuti.

DIAGNOSIS. C. roc sp.n. is distinctive by the following characteristic features: the pale coloring of fore wing with evenly spaced line strokes; the long poorly expressed crest with a small process on its inner surface in the distal third on the costal margin of the valve; the short thick uncus.

ETYMOLOGY. The new species is named after Roc - a legendary huge predatory bird.

\section{Camellocossus jinn Yakovlev et Witt, sp.n.} Figs 7, 15, 22-23.

MATERIAL. Holotype, $\sigma^{7}$, Sudan, Provinz Nahr an Nil, 390 m, N16²5.189', E33 ${ }^{\circ} 14.575^{\prime}, 20$ March 2010, leg. Harald Sulak (Museum Witt, Munich; GenPr Heterocera MWM 25.273).

DESCRIPTION. Length of fore wing $15 \mathrm{~mm}$. Antennae short, in length equal to $1 / 3$ of fore wing costal margin. Head and patagia pale brown from above; thorax and abdomen densely covered with pale ocher (almost white) scales. Fore wing pale ocher with thin undulated pattern more expressed in postdiscal and submarginal areas; in postdiscal area undulated pattern thickens and forms two unequal broken bands; fringe pale yellow, unicolorous. Hind wing pale ocher with hardly expressed singular dark transverse strokes.

Male genitalia. Uncus elongated, rather wide, apex tapered; tegumen of medium size; gnathos arms thin, of medium length; gnathos of medium size, densely covered with small spikes; valve wide with parallel margins, its costal margin with large pyramidal crest with three transverse crests on inner surface in its distal third, sacculus of medium size, apex of valve slightly tapered; transtilla process of medium length, evenly curved, gradually narrowing from base to apex, apex tapered; juxta large, heavily sclerotized with wide leaf-like lateral processes diluted at an angle of $120^{\circ}$, upper edge of lateral process of juxta semicircular, lower edge even; saccus of medium size, semicircular; phallus thick, straight, in length about $4 / 5$ of valve, vesica aperture in dorso-apical position, in length about $1 / 2$ of phallus; vesica without cornuti.

DIAGNOSIS. C. jinn sp.n. is distinctive by the following characteristic features: the color of the head and patagia contrasting to the thorax and abdomen (the head and patagia brown; the thorax and abdomen pale ocher, almost white); the costal margin of the valve with a large pyramidal crest with three transverse crests on its inner surface in the distal third; the semicircular upper edge and the even lower edge of the lateral process of the juxta.

ETYMOLOGY. The new species is named after Jinn a character of Arabian tales.

\section{Camellocossus ifrit Yakovlev et Witt, sp.n.}

$$
\text { Figs 8, 16, } 23 .
$$

MATERIAL. Holotype, $\sigma^{7}$, Sudan, env. SE Bahr al Azraq, Wad Madini, $540 \mathrm{~m}, \mathrm{~N} 14^{\circ} 25.069^{\prime}, \mathrm{E} 33^{\circ} 37.553^{\prime}, 28$ March 2010, leg. Harald Sulak (Museum Witt, Munich; GenPr Heterocera MWM 25.273). Paratypes, $2 \sigma^{\top}$, same data as holotype (Museum Witt, Munich).

DESCRIPTION. Length of fore wing $15 \mathrm{~mm}$. Antennae short, in length equal to $1 / 3$ of fore wing costal margin. Head, thorax and abdomen densely covered with dark grey scales. Fore wing dark grey with thin undulated pattern developed throughout wing; undulated pattern thickens in postdiscal area, poorly expressed blurred brown portions in cubital area, thin transverse dark grey band from costal margin to vein $\mathrm{M}_{3}$ in submarginal area; fringe dark grey, unicolorous. Hind wing grey with hardly expressed singular dark transverse strokes.

Male genitalia. Uncus elongated, relatively thin with tapered apex; tegumen of medium size; gnathos arms thin, of medium length; gnathos of medium size, densely covered with small spikes; valve wide with smoothly rounded costal margin and even lower margin, on costal margin weakly expressed crest with poorly expressed battlement along the edge in distal third, sacculus of medium size, apex of valve rounded; transtilla process relatively short, evenly curved, gradually narrowing from base to apex, apex tapered; juxta large, heavily sclerotized, in form of cone with apex directed to saccus, with wide leaf-like lateral processes with parallel edges diluted at an angle of $170^{\circ}$; saccus of medium size, semicircular; phallus thick, straight, in length equal to valve, vesica aperture in dorso-apical position, in length about $1 / 2$ of phallus; vesica without cornuti.

DIAGNOSIS. C. ifrit sp.n. is distinctive by the following characteristic features: the dark color of the wings; the valve with a smoothly rounded costal margin and even lower margin; the costal margin of the valve with a weakly expressed crest slightly serrated along the edge in distal third; the juxta in the form of a cone with the apex directed to the saccus.

ETYMOLOGY. The new species is named after Ifrit - a character of Arabian tales.

Camellocossus strohlei Yakovlev et Witt, sp.n. Figs 9, 17, 23.

MATERIAL. Holotype, $\sigma^{\top}$, Ethiopia, Arba Minch, $06^{\circ} 07^{\prime} 48^{\prime \prime} \mathrm{N} /$ 37³4'41''E, $1465 \mathrm{~m}, 22.02 .2010$, leg. Ströhle (collection of M. Ströhle, Weiden, Coss-MSW/2015/12). Paratypes: 1 ๙ , Ethiopia, same data as holotype (collection of M. Ströhle, Weiden); $7 \sigma^{7} \sigma^{7}$, Ethiopia, Turmi, Mango Lodge, 0432N/036 $54 \mathrm{E}, 920 \mathrm{~m}$, 21"24.01.2015, leg. Ströhle (collection of M. Ströhle, Weiden, Coss-MSW/2015/11).

DESCRIPTION. Length of fore wing $13 \mathrm{~mm}$. Antennae short, in length equal to $1 / 3$ of fore wing costal margin. Head and patagia brown from above; thorax and abdomen densely covered with pale brown scales. Fore wing pale brown with thin undulated pattern more developed in postdiscal and submarginal areas; in postdiscal area two uneven broken bands with brown portion between them, brown portion 
along hind margin; fringe pale grey, unicolorous. Hind wing pale ocher with hardly expressed singular dark transverse strokes and pale ocher unicolorous fringe.

Male genitalia. Uncus short, relatively wide with blunt apex; tegumen of medium size; gnathos arms thick, of medium length; gnathos of medium size, densely covered with small spikes; valve wide, strongly concave, cupped, costal margin curved in basal third, hind margin curved in middle third, medium semicircular crest with one transverse crest on its inner surface on costal margin of valve in distal third, sacculus of medium size, apex of valve slightly tapered; transtilla process of medium length, evenly curved, gradually narrowing from base to apex, apex tapered; juxta large heavily sclerotized with relatively narrow leaf-like lateral process-

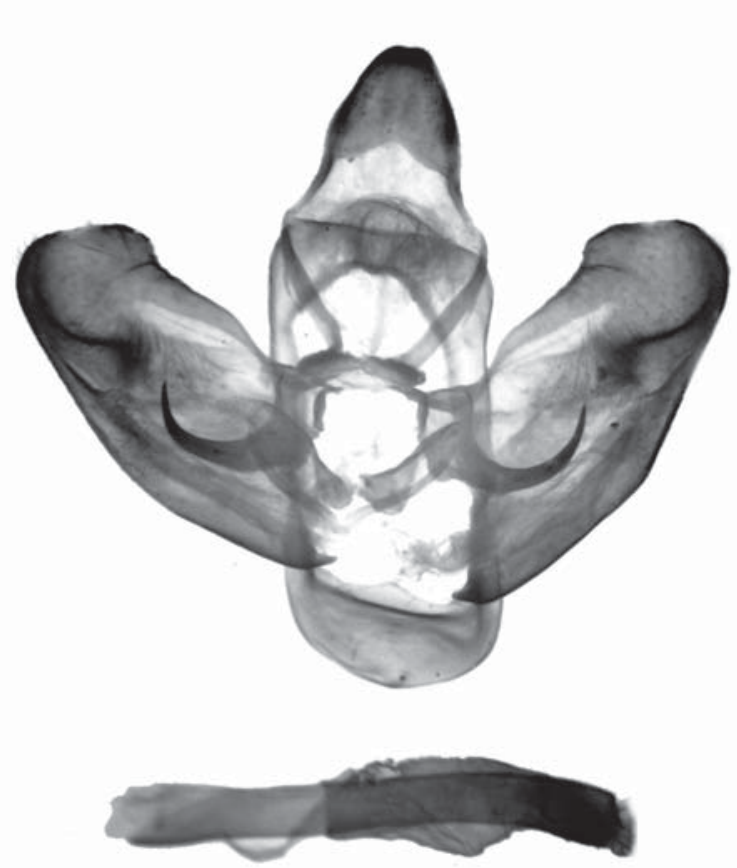

17

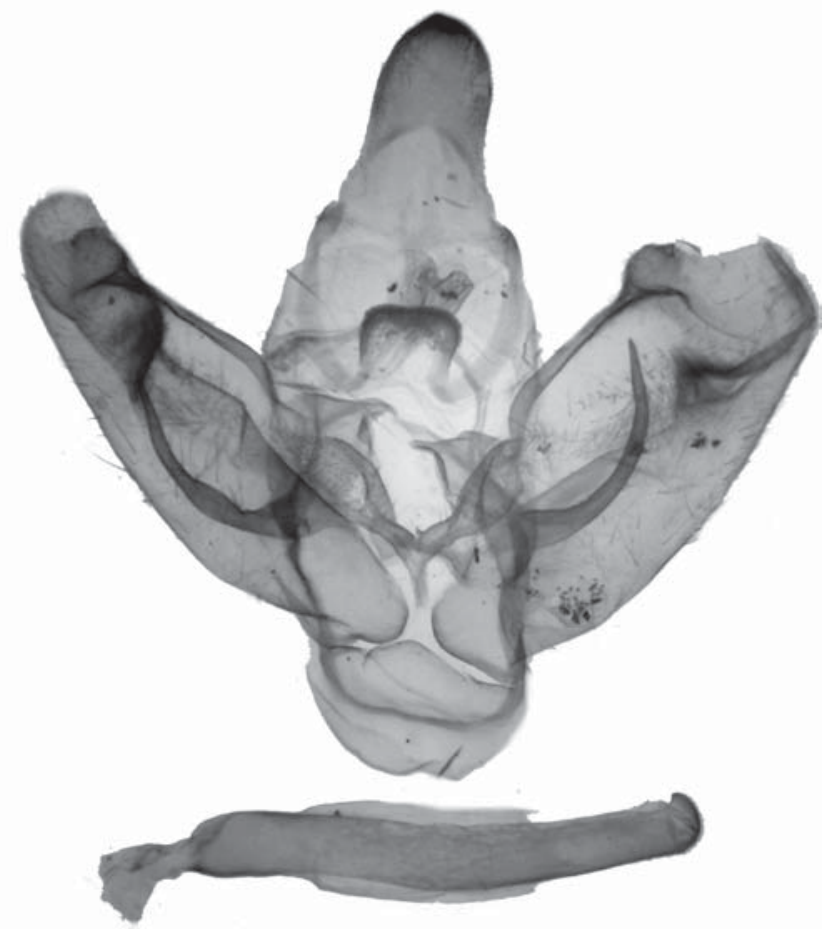

18

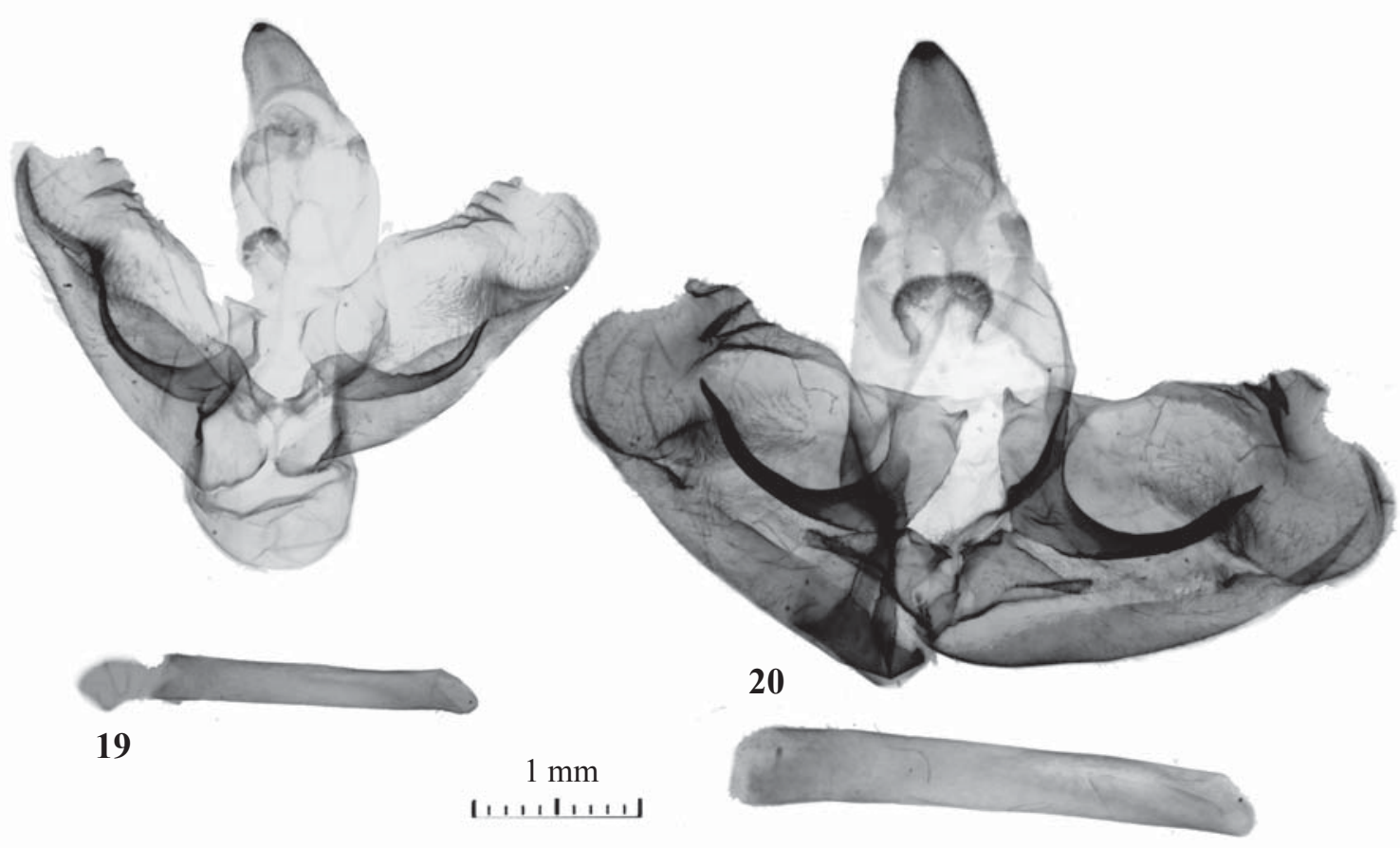

Figs 17-20. Male genitalia of Camellocossus species: $17-$ C. strohlei Yakovlev et Witt, sp.n.; 18 - C. lalibela Yakovlev et Witt, sp.n.; $19-$ C. snizeki Yakovlev et Witt, sp.n.; $20-$ C. ngai Yakovlev et Witt, sp.n.

Рис. 17-20. Гениталии самцов видов Camellocossus: 17 - C. strohlei Yakovlev et Witt, sp.n.; 18 - C. lalibela Yakovlev et Witt, sp.n.; $19-$ C. snizeki Yakovlev et Witt, sp.n.; $20-$ C. ngai Yakovlev et Witt, sp.n. 
es with almost parallel edges, diluted at an angle of $100^{\circ}$; saccus large, semicircular; phallus thick, slightly curved in proximal third, in length about $4 / 5$ of valve, vesica aperture in dorso-apical position, in length about $1 / 3$ of phallus; vesica without cornuti.

DIAGNOSIS. C. strohlei sp.n. is distinctive by the following characteristic features: the uncus with a blunt apex; the cupped valve with the costal margin curved in its basal third and the hind margin curved in its middle third; the costal margin of the valve in the distal third with a medium semicircular crest with one transverse crest on its inner surface.

ETYMOLOGY. The new species is named after the German lepidopterist Manfred Ströhle (Weiden).

\section{Camellocossus lalibela Yakovlev et Witt, sp.n.} Figs 10, 18, 23.

MATERIAL. Holotype, $\sigma^{\top}$, Ethiopia, Arba Minch, 0559' $56^{\prime \prime} \mathrm{N} /$ 37³2'54'’E, 1380 m, 13.11"4.12.2011, leg. Ströhle (collection of M. Ströhle, Weiden, Coss-MSW/2015/13). Paratype, $1 \sigma^{7}$, Ethiopia, same data as holotype (collection of M. Ströhle, Weiden).

DESCRIPTION. Length of fore wing $18 \mathrm{~mm}$. Antennae short, in length equal to $1 / 3$ of fore wing costal margin. Head, thorax and abdomen densely covered with brown scales. Fore wing dark grey with thin undulated pattern more developed in postdiscal and submarginal areas; undulated pattern thicker in postdiscal area, poorly expressed blurred brown portions in cubital area, thin transverse dark grey band from costal margin to vein $M_{3}$ in submarginal area; fringe dark grey, unicolorous. Hind wing pale grey with hardly expressed singular dark transverse strokes.

Male genitalia. Uncus elongated, thick, apex tapered; tegumen of medium size; gnathos arms thick, of medium length; gnathos of medium size, densely covered with small spikes; valve wide with almost parallel margins, costal margin with strongly expressed sclerotized even crest (from base to distal third), costal margin of valve in distal third with strongly expressed semicircular crest, its inner surface with large sclerotized obliquely positioned rib, sacculus strongly expressed, apex of valve rounded; transtilla process long, thin, evenly curved, gradually narrowing from base to apex, apex tapered; juxta large, heavily sclerotized, in form of cone with apex directed to saccus, with very wide leaf-like lateral processes diluted at an angle of $120^{\circ}$ with heavily sclerotized costal and lower margin and membranous middle area; saccus large, semicircular; phallus thick, slightly curved in medium third, in length equal to $4 / 5$ of valve, vesica aperture in dorso-apical position, in length about $1 / 2$ of phallus; vesica without cornuti.

DIAGNOSIS. C. lalibela sp.n. is distinctive by the following characteristic features: relatively large size (length of the fore wing $18 \mathrm{~mm}$ ); the costal margin of the valve with a strongly expressed sclerotized even crest (from the base to the distal third), the distal third of the valve costal margin with a strongly expressed semicircular crest with a large sclerotized obliquely positioned rib on its inner surface; the lateral processes of the juxta with strongly sclerotized costal and lower margins and a membranous middle area.

ETYMOLOGY. The new species is named after Gebre Mesqel Lalibela - king of Ethiopia and a member of the Zagwe dynasty.

\section{Camellocossus snizeki Yakovlev et Witt, sp.n.} Figs 11, 19, 23.

MATERIAL. Holotype, O’, Kenya E, 202 km E Thika, Sosoma, 24.4.2011, leg. Sni•ek (Museum Witt, Munich; GenPr Heterocera
MWM 25.276). Paratype, $\sigma^{7}$, same data as holotype (Museum Witt, Munich).

DESCRIPTION. Length of fore wing $12 \mathrm{~mm}$. Antennae short, in length equal to $1 / 3$ of fore wing costal margin. Head, thorax and abdomen densely covered with brown scales. Fore wing dark grey with thin undulated pattern more developed in postdiscal and submarginal areas; brown portion from wing base to border of discal and postdiscal areas, thin transverse dark grey band from costal margin to vein $M_{3}$ in submarginal area; fringe dark grey, unicolorous. Hind wing pale grey with dense dark transverse strokes.

Male genitalia. Uncus short, of medium thickness, apex tapered; tegumen of medium size; gnathos arms thin, of medium length; gnathos of medium size, densely covered with small spikes; valve wide, costal margin curved in proximal third, hind margin practically even, costal margin (in distal third) with strongly expressed crest with serrated edge and four sclerotized ribs on inner surface, sacculus of medium size, apex of valve rounded; transtilla process long, thin, evenly curved, gradually narrowing from base to apex, apex tapered; juxta large, heavily sclerotized in form of cone with apex directed to saccus, with wide leaf-like lateral processes diluted at an angle of $120^{\circ}$; saccus large, semicircular; phallus thick, slightly curved in medial third, in length equal to 4/ 5 of valve, vesica aperture in dorso-apical position, in length about $1 / 2$ of phallus; vesica without cornuti.

DIAGNOSIS. C. snizeki sp.n. is distinctive by the following characteristic features: relatively small size (length of fore wing $12 \mathrm{~mm}$ ); the costal margin of the valve (in distal third) with a strongly expressed crest with serrated edge and four sclerotized ribs on the inner surface.

ETYMOLOGY. The new species is named after the Czech coleopterist Miroslav Snižek.

Camellocossus ngai Yakovlev et Witt, sp.n. Figs 12, 20, 23.

MATERIAL. Holotype, $\sigma^{7}$, Kenya CEE, E of Garsen, W of Witu, 18"20.12.2009, leg. Sni•ek (Museum Witt, Munich; GenPr Heterocera MWM 25.268). Paratype, $1 \sigma^{\gamma}$, same data as holotype (Museum Witt, Munich).

DESCRIPTION. Length of fore wing $19 \mathrm{~mm}$. Antennae short, in length equal to $1 / 3$ of fore wing costal margin. Head, thorax and abdomen densely covered with pale grey scales. Fore wing grey with thin undulated pattern more developed in postdiscal and submarginal areas; in postdiscal area pattern thickens forming undulated band from costal to hind margin; brown portion developed along hind margin; thin transverse dark grey band from costal margin to vein $M_{1}$ in submarginal area; fringe pale grey, unicolorous. Hind wing pale grey with dense dark transverse strokes.

Male genitalia. Uncus relatively long, of medium thickness, apex tapered; tegumen of medium size; gnathos arms thin, of medium length; gnathos of medium size, densely covered with small spikes; valve wide, costal margin curved in medium third, hind margin practically even, on costal margin of valve (in distal third) strongly expressed crest with serrated edge and three sclerotized ribs on its inner surface, sacculus of medium size, apex of valve rounded; transtilla process long, thick, heavily sclerotized, evenly curved, gradually narrowing from base to apex, apex tapered; juxta large, heavily sclerotized, with wide leaf-like lateral processes diluted at an angle of $180^{\circ}$, lateral processes triangle, evenly narrowing from base to apex; saccus large, semicircular; phallus thick, even, in length equal to valve, vesica aperture in dorso-apical position, in length about $1 / 2$ of phallus; vesica without cornuti. 

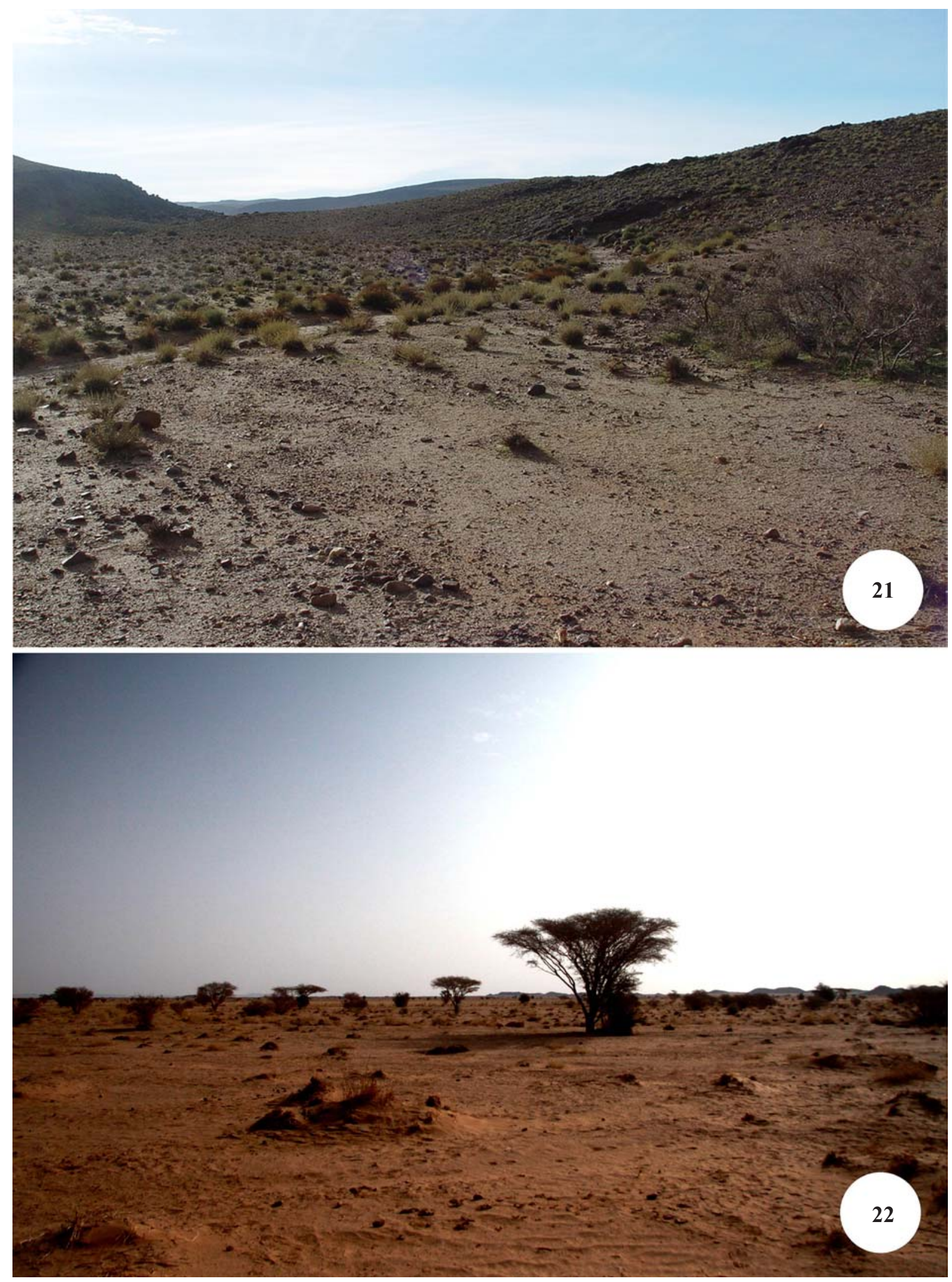

Figs 21-22. Type localities of Camellocossus species: $21-$ C. aladdin Yakovlev et Witt, sp.n.; $22-$ C. jinn Yakovlev et Witt, sp.n. Photo by H. Sulak.

Рис. 21-22. Типовая местность видов Camellocossus: 21 - C. aladdin Yakovlev et Witt, sp.n.; 22 - C. jinn Yakovlev et Witt, sp.n. Фото H. Sulak. 
DIAGNOSIS. C. ngai sp.n. is distinctive by the following characteristic features: relatively large size (length of the fore wing $19 \mathrm{~mm}$ ); the costal margin of the valve (in distal third) with a strongly expressed crest with a serrated edge and three sclerotized ribs on its inner surface; the triangle lateral processes of the juxta, evenly narrowing from the base to the apex.

ETYMOLOGY. The new species is named after Ngai the supreme deity in the beliefs of the Masai tribe.

\section{Discussion}

Camellocossus includes 12 widespread species of the Arabian Peninsula, North Africa (Morocco, Mauritania, Algeria, Egypt, Sudan) and East Africa (Ethiopia, Kenya, Somalia). Camellocossus is one of the Cossidae genera (except for Aethalopteryx Schoorl, 1990 (type species Phragmatoecia atrireta Hampson, 1910), Afroarabiella Yakovlev, 2008 (type species Cossus tahamae Wiltshire, 1949), Afrikanetz Yakovlev, 2009 (type species - A. inkubu Yakovlev, 2009), Mormogystia Schoorl, 1990 (type species Cossus reibellit Oberthür, 1876), widespread in Arabia, Africa and the Sahara. Apparently the Sahara has not been a barrier to the dispersal of these Cossidae genera [Yakovlev, Dubatolov,
2013; Yakovlev, 2015]. Ten species of the genus Afroarabiella are found in different regions of Africa (1 species in West Africa, 6 species in East Africa, 2 species in South Africa, 1 species in Sahel) and one (A. tahamae) in South and Central Arabia. The genus Aethalopteryx includes 24 species; 23 of them are widespread in Africa (9 in East Africa, 5 in South Africa, 3 in Central Africa, 1 in Sahel, 4 - all over Africa), one species (A. diksami Yakovlev et Saldaitis, 2010) in Socotra, and one (A. wiltshirei Yakovlev, 2009) in Central Arabia. A similar situation is apparent in the genus Afrikanetz Yakovlev, 2009. Among its three described species, $A$. inku$b u$ is found in West Congo (the Republic of Congo), $A$. bugvan Yakovlev, 2009 is recorded for several countries in West Africa, A. makumazan Yakovlev, 2009 was described from the Western Kingdom of Saudi Arabia [Yakovlev, 2009]. In the genus Mormogystia three species are known. M. reibellii Oberthür, 1876 is recorded from the Kingdom of Saudi Arabia, Oman, UAE, Yemen, Israel, Egypt, Algeria, Libya, Tunisia, Mauritania, Niger, Chad [Yakovlev, 2011]; M. brandstetteri Saldaitis, Ivinskis et Yakovlev, 2011 is widespread on Socotra; Mormogystia equatorialis (Le Cerf, 1933 ) is described from the environs of lake Turcan (North Kenia). The question of the origin of these genera (Palaearctic or Palaetropic) is unresolved until a phylogenetic analysis is completed.

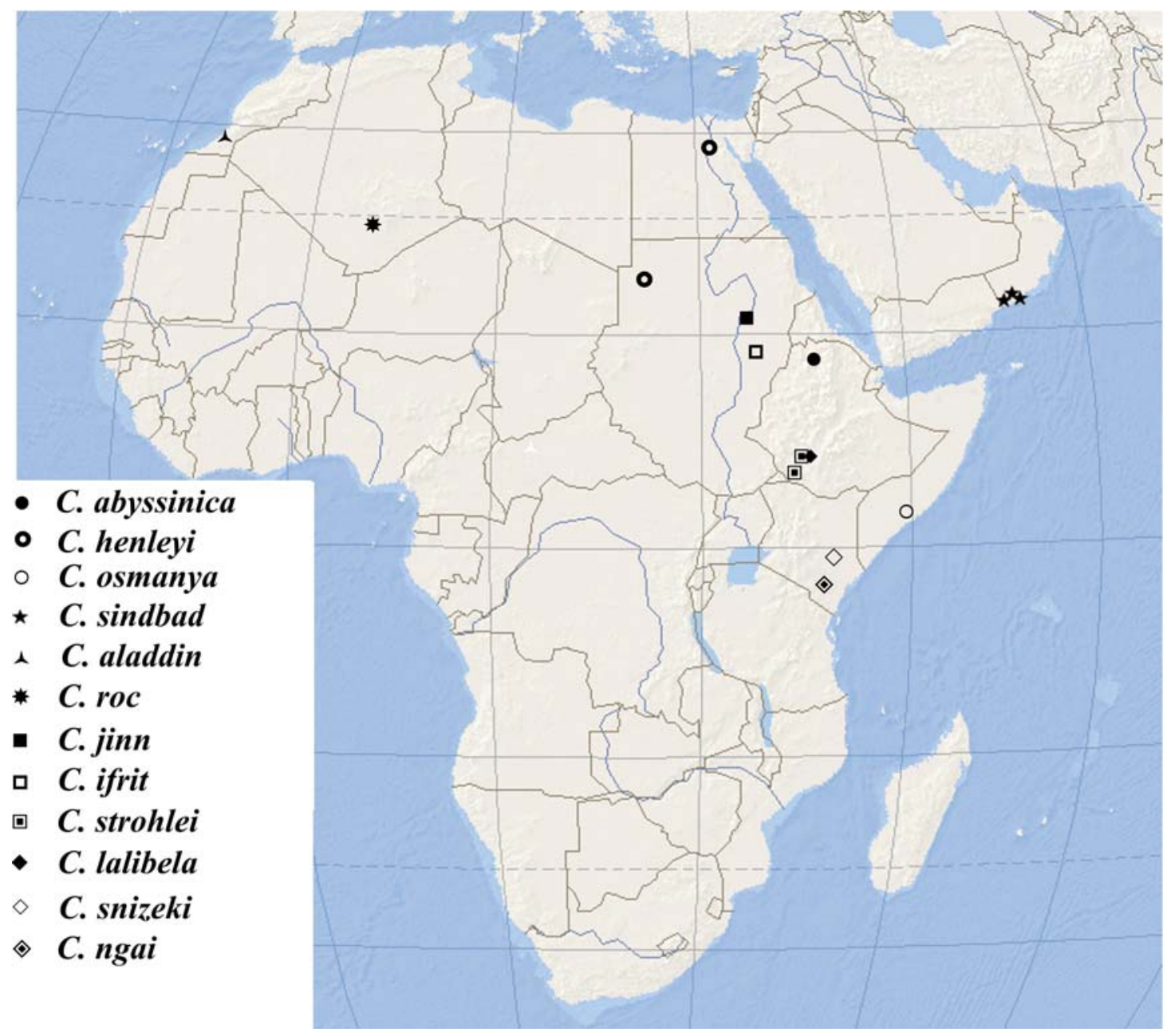

Fig. 23. Map of Camellocossus species distribution.

Рис. 23. Карта распространения видов рода Camellocossus. 
ACKNOWLEDGEMENTS. We are indebted to the BMNH Council of Trustees for kindly granting the permission to publish images of the type specimens preserved in the Natural History Museum. The authors are grateful to Anna Ustjuzhanina (Tomsk, Russia) and Prof. Boris Kondratieff (Fort Collins, USA) for language improvements and to Manfred Ströhle (Weiden, Germany) for permission to work with specimens from his private collection.

\section{References}

Lafontaine J.D. 2004. Noctuoidea, Noctuidae (part), Noctuinae (part"Agrotini) // R.W. Hodges (ed.). The Moths of America North of Mexico, fasc.27.1. Washington: The Wedge Entomological Research Foundation. 385 pp.
Hampson G.F. 1910. Descriptions of a new African Moths // The Annals and magazine of natural history. Vol.8. No.6. P.116135. http://dx.doi.org/10.1080/00222931008692829

Warren W., Rothschild Ch. 1905. Lepidoptera from Sudan // Novitates Zoologicae. Vol.12. P.21-28.

Yakovlev R.V. 2011. Catalogue of the Family Cossidae of the Old World // Neue Entomologische Nachrichten. Bd.66. S.1-129.

Yakovlev R.V. 2015. Patterns of Geographical Distribution of Carpenter Moths (Lepidoptera: Cossidae) in the Old World // Contemporary Problems of Ecology. Vol.8. No.1. P.36-50. http://dx.doi.org/10.1134/S1995425515010151

Yakovlev R.V., Dubatolov V.V. 2013b. Distribution of CarpenterMoths (Lepidoptera, Cossidae) in the Palaearctic Deserts // Entomological Review. Vol.93. No.8. P.991-1004. http:// dx.doi.org/10.1134/S0013873813080071

Yakovlev R.V., Saldaitis A., Rimsaite J., Ivinskis P. 2015. A new species of Camellocossus Yakovlev, 2011 (Lepidoptera: Cossidae) from Southern Oman // Zootaxa. Vol.4013. No.1. P.147-150. http://dx.doi.org/10.11646/zootaxa.4013.1.12 